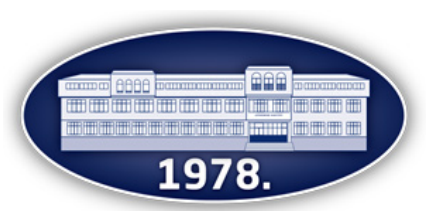

\title{
Differences in iron accumulation in the grain between and within Aegilops and Triticum species
}

\author{
Rudolf Kastori ${ }^{1}$, Ivana Maksimović ${ }^{*}$, Vojislava Momčilović ${ }^{2}$, Milan Mirosavljević ${ }^{2}$, \\ Marina Putnik-Delić ${ }^{1}$, Milena Daničič ${ }^{1}$ \\ 1 University of Novi Sad, Faculty of Agriculture, Department of Field and Vegetable Crops, Trg Dositeja Obradovića 8, \\ 21000 Novi Sad, Serbia \\ 2 Institute of Field and Vegetable Crops, Maksima Gorkog 30, 21000 Novi Sad, Serbia \\ *Corresponding author: ivana.maksimovic@polj.uns.ac.rs
}

Received 19 March 2021; Accepted 2 September 2021

\begin{abstract}
A B S T R A C T
Plants are the most important source of Fe for humans and animals; therefore, its accumulation in edible plant parts is of great importance. Since plant species, ecotypes, genotypes, lines, and varieties may differ in their ability to accumulate mineral elements, the aim of this study was to i) examine the accumulation of Fe in the grain of Aegilops and Triticum species with different genomes (AA, BB, BBAA, BBAADD), ii) study the relationship between the level of ploidy and grain Fe accumulation, and iii) analyze correlations between grain size and Fe concentration. Twenty different genotypes were included in three-year field experiments. The examined species and genotypes differed significantly with respect to grain Fe concentration, which was the highest in diploid Aegilops speltoides (BB genome). Tetraploid and modern cultivated hexaploid varieties displayed substantial variation in Fe concentration in the whole grain. Genotypes also differed significantly in thousand grain weight (TGW), which was the smallest in Aegilops speltoides. A significant negative correlation was found between grain Fe concentration and TGW, and a positive correlation between TGW and Fe content in individual grains. The higher accumulation of Fe in individual grains of tetraploid and hexaploid wheat vs. diploid ancestors suggests that the increase in ploidy led to an increase in the capacity of grains to serve as a sink for that Fe. The results indicate that genetic diversity in the wheat genome is sufficient to allow a significant increase in Fe concentration in the wheat grain.
\end{abstract}

Keywords: whole grain, iron concentration, grain size, diploid, tetraploid, hexaploid wheat.

\section{И 3 В $О$ Д}

Биљке представљају најважнији извор Fe за људе и животиње; зато је његово накупљање у јестивим деловима биљака веома значајно. Пошто биљне врсте, екотипови, генотипови, линије и сорте могу да се разликују у накупљању минералних материја, циљ овог рада је био да се испита накупљање Fе у зрну врста Aegilops и Triticum које се одликују различитим геномима (AA, BB, BBAA, BBAADD), ii) истражи однос између нивоа плоидности и накупљања Fе у зрну и іiі) анализира међузависност величине зрна и концентрације Fе. Двадесет различитих генотипова је било укључено у трогодишње пољске огледе. Испитиване врсте и генотипови су се значајно разликовали по концентрацији Fе у зрну, при чему је највиша установљена у зрну диплоидног Aegilops speltoides (ВВ геном). Тетраплоидни и савремени гајени хексаплоидни генотипови показали су значајне разлике у концентрацији Fе у целом зрну. Испитивани генотипови су се значајно разликовали и по маси хиљаду зрна (TGW), која је била најмања код Aegilops speltoides. Значајна негативна међузависност је установљена између концентрације Fe у зрну и TGW, док је позитивна установљена између TGW и садржаја Fe у појединачним зрнима. Веће накупљање Fe у појединачним зрнима тетраплоидних и хексаплоидних генотипова у односу на диплоидне претке указује на то да је током повећања плоидности повећана и способност накупљања Fe у зрну. Резултати указују на то да у геному пшенице у целини постоји довољна генетичка разноликост која може да се искористи за значајно повећање концентрације Fе у зрну пшенице.

Кључне речи: цело зрно, концентрација гвожђа, величина зрна, диплоидна, тетраплоидна, хексаплоидна пшеница.

\section{Introduction}

Iron is present in all parts of the biosphere. It is the second most abundant metal in the Earth's crust, after Al. It directly or indirectly affects numerous physiological processes in plants and all other organisms. Therefore, Fe deficiency limits the growth and development of plants, reduces the yield and nutritive value of food, but also provokes many diseases in humans (Edison et al., 2008; Broadley et al., 2012; Barker et al., 2015). The deficiency of Fe in forms available to plants in the soil is widespread all over the world. Globally, lack of $\mathrm{Fe}$, alongside $\mathrm{Zn}$, is the most widespread compared with all the other essential elements for plants. The causes of the lack of available forms of $\mathrm{Fe}$ in the soil, regardless of its overall relative 
abundance in the soil, are very diverse and specific for climatic, pedological and soil management conditions (Kabata-Pendias, 2000). Nevertheless, Fe deficiency generally occurs on alkaline soils rich in clay, in arid and semi-arid regions. The lack of one or several essential nutrients in agricultural soils is widely spread, on several millions of hectares (Welch et al., 1991).

In many regions of the world, due to the insufficient content of $\mathrm{Fe}$ in the soil, its concentration in plant-derived food is insufficient to meet the needs of the human diet. Together with iodine and vitamin A, iron is the most important in global public health terms; its deficiency represents a major threat to the health and development of populations worldwide, particularly children and pregnant women in lowincome countries (WHO, 2020). Poor nutrition increases the vulnerability of children. One in five children in the poorest parts of the world will not live longer than their fifth birthday, mainly because of environment-related diseases. For example, $\mathrm{Pb}$ is known to be more toxic to children whose diets are deficient in calories, Fe and Ca (WHO, 2007). According to WHO (2011) nearly 3.7 billion people in the world consume insufficient amounts of Fe. Since plants are the principal source of Fe for humans, the increase in its concentration in edible plant parts, along with an increase in its availability provided by crop breeding and other biotechnical procedures, is of great importance (Frossard et al., 2000; Weich and Graham, 2004). In many parts of the world, small grains are often the most commonly grown and processed crops, with wheat having a special place in the processed food industry and human nutrition.
Grain Fe concentration in small grain crops and products processed from them is often low. Since this type of food is abundantly present in the diet, Fe deficiency often occurs. In crop breeding programs, far more attention is generally given to crop yield than to the nutritional quality of products (Morris and Sands, 2006). Wheat breeding aimed at increasing the content of $\mathrm{Fe}$ in the grain requires knowledge of its content in the available germplasm. Many results suggest that there is significant variability in the concentration of $\mathrm{Fe}$ in the grain of different cultivars and lines of wheat (Welch and Graham, 2004; Graham et al., 1999; Zhao et al., 2009). The concentration of micronutrients in the grain is important for initial seedling growth and crop productivity, especially under conditions of micronutrient deficiency, which may occur due to unfavorable biotic and abiotic factors (Duxbury et al., 2005). Insufficient concentrations of micronutrients reduce the viability and vigor of seeds (Welch, 1999).

In the present study, the objective was to assess the influence of species, genomic structure, ploidy level and growing season on Fe accumulation in the whole wheat grain.

\section{Materials and methods}

\subsection{Plant material}

Six diploid genotypes of wheat with different genomes (BB, AA, or DD), five tetraploids (BBAA) and nine hexaploids (BBAADD) were used in the experiment (Table 1).

Table 1.

Genotypes of Aegilops and Triticum species (classified according to van Slagreren, 1994) examined in the experiments (Maksimović et al., 2020)

\begin{tabular}{|c|c|c|c|c|c|}
\hline No. & Species and subtaxa & Name & Genome(s) & Accession name & Source \\
\hline 1 & $\begin{array}{llll}\begin{array}{l}\text { Aegilops } \\
\text { speltoides }\end{array} & \text { speltoides } & \text { TAUSCH } & \text { var. } \\
\end{array}$ & - & $\mathrm{BB}$ & - & $\mathrm{D}^{*}$ \\
\hline 2 & $\begin{array}{l}\text { Aegilops speltoides TAUSCH var. } \\
\text { speltoides }\end{array}$ & - & $\mathrm{BB}$ & - & $\mathrm{D}$ \\
\hline 3 & Triticum urartu THUM. ex GANDIL. & Red wild einkorn & AA & - & RS \\
\hline 4 & Triticum monococcum $\mathrm{L}$. & Wild einkorn & AA & Tr. Monococcum & RS \\
\hline 5 & $\begin{array}{l}\text { Triticum monococcum L. var. } \\
\text { monococcum }\end{array}$ & Cultivated einkorn & AA & Krupnik & $\mathrm{RS}$ \\
\hline 6 & Aegilops tauschii COSS. & Tausch's goatgrass & DD & - & $\mathrm{D}$ \\
\hline 7 & $\begin{array}{l}\text { Triticum dicoccoides (KOERN. ex } \\
\text { ASCHERS. et GRAEBN.) SCHWEINF. }\end{array}$ & Wild emmer & BBAA & - & $\mathrm{D}$ \\
\hline 8 & $\begin{array}{l}\text { Triticum turgidum L. var. rubralbum } \\
\text { FLAKSB. }\end{array}$ & Wild emmer & BBAA & - & RS \\
\hline 9 & Triticum turgidum L. var. turgidum & Cultivated emmer & BBAA & - & RS \\
\hline 10 & Triticum turgidum L. & Rivet wheat & BBAA & $\begin{array}{l}\text { Berkners } \\
\text { Rauhweizen }\end{array}$ & $\mathrm{D}$ \\
\hline 11 & $\begin{array}{l}\text { Triticum durum DESF. var. } \\
\text { pseudosalomonis PAPAD. }\end{array}$ & Durum wheat & BBAA & Durumko 1 & RS \\
\hline 12 & $\begin{array}{l}\text { Triticum spelta L. var. duhamelianum } \\
\text { (MAZZ.) KOERN. }\end{array}$ & Spelt wheat & BBAADD & - & RS \\
\hline 13 & $\begin{array}{l}\text { Triticum aestivum L. var. lutescens } \\
\text { (ALEF.) MANSF. }\end{array}$ & Common wheat & BBAADD & Panonia & RS \\
\hline 14 & $\begin{array}{l}\text { Triticum aestivum L. var. lutescens } \\
\text { (ALEF.) MANSF. }\end{array}$ & Common wheat & BBAADD & Bankut 1205 & $\mathrm{H}$ \\
\hline 15 & Triticum aestivum $\mathrm{L}$. & Common wheat & BBAADD & Besostaya 11 & RUS \\
\hline 16 & Triticum aestivum $\mathrm{L}$. & Common wheat & BBAADD & Italyan & MEX \\
\hline 17 & Triticum aestivum $\mathrm{L}$. & Common wheat & BBAADD & Florida & $\mathrm{D}$ \\
\hline 18 & Triticum aestivum L. var. aestivum & Common wheat & BBAADD & Renan & $\mathrm{F}$ \\
\hline 19 & Triticum aestivum L. & Common wheat & BBAADD & Condor & AUS \\
\hline 20 & Triticum aestivum L. & Common wheat & BBAADD & Bolal & TR \\
\hline
\end{tabular}

*D, Germany; RS, Serbia; H, Hungary; RUS, Russia; MEX, Mexico; F, France; AUS, Australia, TR, Turkey. For details comprising the accession numbers of studied genotypes please refer to the paper Kastori et al. (2017). 
Among the diploid wheats, four were wild and one (Triticum monococcum var. monococcum) was a primitive cultivated wheat. Among the tetraploids, two genotypes were wild emmer; one was rivet wheat, and two were cultivated. All hexaploids were cultivated genotypes. This choice of genotypes allowed a comparison of the grain $\mathrm{Zn}$ accumulation ability of wild and primitive genotypes with that of modern wheat cultivars.

\subsection{Experimental site and setup}

The experiments were established in the experimental fields of the Institute of Field and Vegetable Crops, Novi Sad $\left(45.2^{\circ} \mathrm{N}, 19.5^{\circ} \mathrm{E}, 80 \mathrm{~m}\right.$ altitude), during three consecutive years. The soil of the experimental field was classified as a calcareous, gleyic chernozem (Loamic, Pachic - CH-cc.gl-Ip.ph (IUSS Working Group WRB, 2015)). Wheat genotypes were sown in a randomized complete block design, in three replications. Plot size was $2.5 \mathrm{~m}^{2}$, each plot contained 10 rows, with a row spacing of $10 \mathrm{~cm} ; 400$ seeds were sown per $\mathrm{m}^{2}$. Details on soil and climate data, experimental setup, management practices during the growing season and sample analyses were as described by Kastori et al. (2017).

\subsection{Plant analyses}

Genotypes included in the experiment were harvested at crop maturity and all hulled genotypes were manually de-hulled. All grain samples used for the analysis were visibly intact, without any sign of damage. Milling was performed using a Perten Laboratory Mill 3100 to produce whole-grain meal After digestion of whole-grain meal in a mixture of 10 $\mathrm{ml} \mathrm{HNO}_{3}(65 \%)$ and $2 \mathrm{ml} \mathrm{H}_{2} \mathrm{O}_{2}(30 \%)$ using the microwave technique, total $\mathrm{Fe}$ concentrations were measured by an inductively coupled plasma emission spectrometer (ICP-OES Varian Vista-Pro).

\subsection{Statistical procedures}

For the analysis of variance (ANOVA), a split plot model with blocks combined over years was applied, with the growing season as the main plot and the genome as the subplot. The species were nested within the genome. Means were compared using Tukey's test. The relationship between grain weight, thousand grain weight (TGW), total iron in the grain and $\mathrm{Fe}$ concentration was determined by linear regression. Iron concentration stability was assessed by the regression of $\mathrm{Fe}$ concentration means of individual cultivars against the environmental index and by calculating the deviation from the regression according to Eberhart and Russell (1966). The regression coefficient (bi) was considered an indication of cultivar response to varying environments. In order to illustrate changes in Fe concentration between growing seasons and genomes, box-plots were calculated. All analyses were performed by Infostat (Di Renzo et al., 2018).

\section{Results and discussions}

\subsection{Fe concentrations in grains}

Significant differences between and within Aegilops and Triticum species were found with respect to the concentration of iron (Fe) (Table 2, Figure 1). The concentration of $\mathrm{Fe}$ in the grains of analyzed genotypes in the three-year period varied from 25.4 to $56.0 \mathrm{mg} \mathrm{kg}^{-1}$ of dry matter (DM), which is similar to the average values for wheat grains in different countries (21.8-43.4 $\mathrm{mg} \mathrm{kg}^{-1}$ DM) (Kabata-Pendias, 2000). Over three years, the average concentration of $\mathrm{Fe}$ was highest (and similar) in the grains of two accessions of Aegilops speltoides (53.39 and $56.02 \mathrm{mg} \mathrm{kg}^{-1} \mathrm{DM}$, respectively) bearing exclusively the $\mathrm{BB}$ genome, and it was significantly higher than the concentration in the other genotypes analyzed. Higher average values of grain Fe concentration were also measured in the other diploids bearing the AA genome - Triticum urartum, Triticum monococum and Triticum monococum var. monocuccum (48.13, 47.59 and $38.11 \mathrm{mg} \mathrm{kg}^{-1} \mathrm{DM}$, respectively). The lowest average concentrations were $25.43 \mathrm{mg} \mathrm{kg}^{-1} \mathrm{DM}$ in hexaploid Triticum sativum L. (BBAADD genome) cv. Florida and $26.67 \mathrm{mg} \mathrm{kg}^{-1} \mathrm{DM}$ in tetraploid genome BBAA Triticum durum DESF var. Durumko 1 . The results suggest that the increase in ploidy is concomitant with the decrease in grain $\mathrm{Fe}$ concentration. Moreover, the results emphasize the importance of $\mathrm{BB}$ and $\mathrm{AA}$ genomes as possibly linked with the concentration of Fe in the grain of wheat and its relatives. Plant species differ in their efficiency to uptake, translocate, and accumulate different mineral elements (Mengel, 1982). Differences also exist among genotypes, ecotypes, lines, and varieties within species (Sarić, 1981), as shown in this research as well. Although nutrient utilization efficiency is recognized as an important crop feature in modern agriculture, the difference in the ability to uptake and accumulate mineral elements between wild and cultivated modern genotypes has received less attention. Batten (1986) compared wheats of different ploidy with respect to the uptake and utilization of phosphorus, and concluded that phosphorus use efficiency increased in the following order: hexaploid $>$ tetraploid $>$ diploid. As determined by Cakmak et al. (1999), average $\mathrm{Zn}$ efficiency ratios were $36 \%$ for tetrapoid, $60 \%$ for diploid and $64 \%$ for hexaploid wheats. Significant differences were also found in the accumulation of aluminum between and within Aegilops and Triticum species. The highest concentration of $\mathrm{Al}$ in the grain was reported for wild diploid Aegilops speltoides (BB genome), and the lowest for tetraploids (BBAA genome) (Maksimović et al., 2020). 
Table 2.

Iron concentration in the whole grain and thousand grain weight of Aegilops and Triticum species over 3 years a

\begin{tabular}{|c|c|c|c|c|c|c|c|c|}
\hline \multirow{3}{*}{$\begin{array}{l}\text { Genotype } \\
\text { no }^{\text {b }}\end{array}$} & \multicolumn{3}{|c|}{$\begin{array}{l}\text { Fe concentration in the whole grain } \\
\text { (mg kg-1 DM) }\end{array}$} & \multicolumn{5}{|c|}{ Thousand grain weight (g) } \\
\hline & \multicolumn{3}{|c|}{ Year } & \multirow{2}{*}{ Average } & \multicolumn{3}{|l|}{ Year } & \multirow{2}{*}{ Average } \\
\hline & 2011 & 2012 & 2013 & & 2011 & 2012 & 2013 & \\
\hline 1 & 43.84 & 56.53 & 59.80 & $53.39 \mathrm{ab}$ & 5.15 & 5.13 & 5.00 & $5.09 \mathrm{j}$ \\
\hline 2 & 46.25 & 58.33 & 63.50 & $56.02 \mathrm{a}$ & 5.77 & 5.67 & 5.68 & $5.70 \mathrm{j}$ \\
\hline 3 & 25.50 & 74.60 & 44.30 & $48.13 \mathrm{abc}$ & 13.93 & 13.80 & 15.05 & $14.26 \mathrm{i}$ \\
\hline 4 & 30.34 & 71.67 & 40.77 & $47.59 \mathrm{abc}$ & 11.56 & 11.58 & 10.83 & $11.32 \mathrm{i}$ \\
\hline 5 & 43.78 & 36.37 & 34.20 & 38.11 bcde & 26.98 & 22.40 & 31.37 & $26.92 \mathrm{~h}$ \\
\hline 6 & 55.76 & 23.57 & 26.07 & 35.13 cde & 13.66 & 13.67 & 12.79 & $13.37 \mathrm{i}$ \\
\hline 7 & 22.41 & 26.97 & 47.33 & $32.23 \mathrm{cde}$ & 25.81 & 19.67 & 32.82 & $26.10 \mathrm{~h}$ \\
\hline 8 & 33.04 & 36.57 & 30.20 & $33.27 \mathrm{cde}$ & 31.14 & 40.20 & 43.29 & $38.21 \mathrm{f}$ \\
\hline 9 & 28.36 & 26.43 & 25.80 & $26.86 \mathrm{e}$ & 32.86 & 31.80 & 27.77 & $30.81 \mathrm{~g}$ \\
\hline 10 & 36.70 & 48.60 & 53.17 & 46.16 abcd & 57.88 & 56.40 & 57.61 & $57.30 \mathrm{a}$ \\
\hline 11 & 28.83 & 22.40 & 22.77 & $24.67 \mathrm{e}$ & 50.71 & 53.53 & 47.68 & $50.64 \mathrm{bc}$ \\
\hline 12 & 32.59 & 39.30 & 44.10 & 38.66 abcde & 51.11 & 48.00 & 54.02 & $51.04 \mathrm{~b}$ \\
\hline 13 & 22.94 & 33.43 & 26.70 & $27.69 \mathrm{e}$ & 42.72 & 44.67 & 40.57 & $42.65 \mathrm{e}$ \\
\hline 14 & 23.01 & 37.10 & 27.90 & $29.34 \mathrm{de}$ & 43.61 & 43.80 & 45.34 & $44.25 \mathrm{de}$ \\
\hline 15 & 33.83 & 44.80 & 37.40 & 38.68 abcde & 49.25 & 48.07 & 49.24 & $48.85 \mathrm{bc}$ \\
\hline 16 & 26.21 & 30.82 & 29.90 & $28.98 \mathrm{de}$ & 37.98 & 37.60 & 38.15 & $37.91 \mathrm{f}$ \\
\hline 17 & 27.39 & 23.50 & 25.40 & $25.43 \mathrm{e}$ & 47.89 & 50.07 & 44.45 & $47.47 \mathrm{~cd}$ \\
\hline 18 & 32.23 & 39.97 & 31.77 & 34.66 cde & 49.18 & 49.13 & 49.93 & $49.41 \mathrm{bc}$ \\
\hline 19 & 25.41 & 32.37 & 34.93 & 30.90 cde & 34.74 & 37.20 & 34.26 & $35.40 \mathrm{f}$ \\
\hline 20 & 24.95 & 53.50 & 35.97 & 38.14 bcde & 48.23 & 45.67 & 52.85 & $48.92 \mathrm{bc}$ \\
\hline Average & 32.01 & 40.84 & 37.10 & & 34.01 & 33.90 & 34.94 & \\
\hline
\end{tabular}

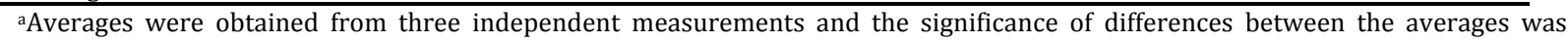
assessed by the LSD test; different letters indicate a significant difference at the $5 \%$ probability level.

bGenotypes of Aegilops and Triticum species examined in the experiments are given in Table 1.

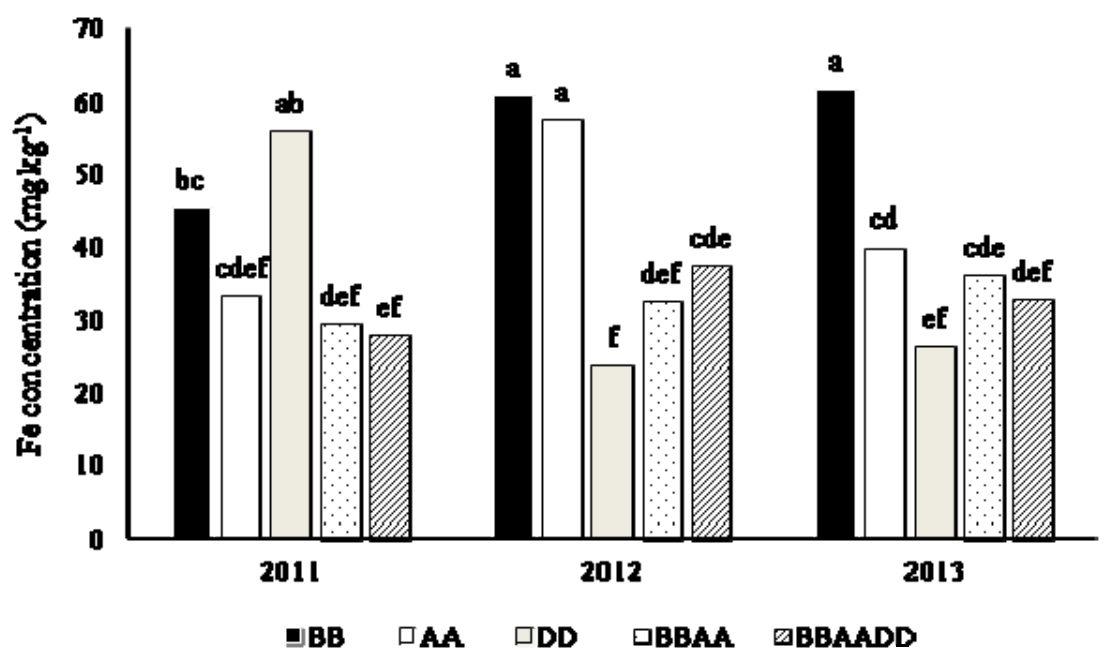

Figure 1. Concentration of iron in the whole grain of five genomes of Aegilops and Triticum

The analysis of variance, with growing season used as a main plot and genome as a sub-plot (a splitplot model with blocks combined over the years), showed significant differences between species, years and their interactions (Table 3a) as well as between genomes, years and interactions (Table $3 b$ ).

\section{Table 3.}

Analysis of variance for the concentration of iron in the whole grain of a) Aegilops and Triticum genotypes and b) five genomes

a)

\begin{tabular}{|c|c|c|c|c|c|c|c|}
\hline \multirow{2}{*}{ Source } & \multirow{2}{*}{$\mathrm{df}$} & \multirow{2}{*}{ SS } & \multirow{2}{*}{ MS } & \multirow{2}{*}{ F-count } & \multicolumn{2}{|c|}{ F-table } & \multirow{2}{*}{ P-value } \\
\hline & & & & & $5 \%$ & $1 \%$ & \\
\hline Year (Y) & 2 & 2352.98 & 1176.4921 & $37.45^{* *}$ & 3.08 & 4.80 & 0.0000 \\
\hline Species (S) & 19 & 14970.62 & 787.9273 & $2.70^{* *}$ & 1.68 & 2.07 & 0.0000 \\
\hline $\mathrm{S}^{*} \mathrm{Y}$ & 38 & 11095.56 & 291.9885 & $34.78^{* *}$ & 1.51 & 1.79 & 0.0000 \\
\hline Error & 114 & 956.97 & 8.3945 & & & & \\
\hline
\end{tabular}


b)

\begin{tabular}{llllll}
\hline Source & df & SS & MS & F & p-value \\
\hline Year $(\mathrm{Y})$ & 2 & 2352.98 & 1176.49 & 27.38 & $<0.0001$ \\
Genome $(G)$ & 4 & 9799.34 & 2449.83 & 57.02 & $<0.0001$ \\
G/G>Species & 15 & 5171.28 & 344.75 & 8.02 & $<0.0001$ \\
$\mathrm{Y}^{*} \mathrm{G}$ & 8 & 5795.95 & 724.49 & 16.86 & $<0.0001$ \\
Error & 150 & 6445.06 & 42.97 & & \\
\hline
\end{tabular}

The level of changes in Fe concentration between the three growing seasons and genomes is shown by a boxplot, where the significance between $\mathrm{Fe}$ concentrations is evident (Figure 2). $\mathbf{a}$

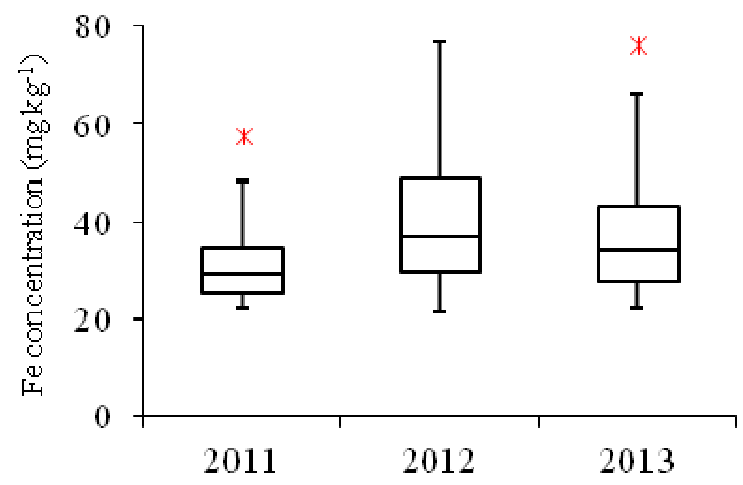

b

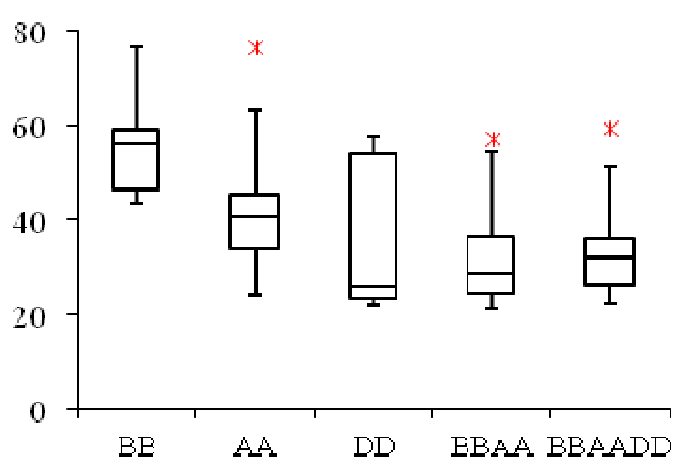

Figure 2. Boxplot of the concentration of iron in the whole grain over three years (a) in five genomes (b)

\subsection{Grain size and Fe concentration}

Grain size depends on genetic and ecological factors and agricultural management practices. Thousand grain weight (TGW) depends primarily on grain size and to a lesser extent on grain chemical composition. Thousand grain weight and grain $\mathrm{Fe}$ concentration between and within Aegilopsis and Triticum species significantly varied (Table 2). The analyses of Fe concentration stability was done by the regression of the mean $\mathrm{Fe}$ concentration of individual cultivars against the environmental index and by calculating the deviation from the regression (Figure 3 ). The regression coefficient (bi) was considered an indication of cultivar response to varying environments. There was a negative correlation between average TGW and grain Fe concentration $\left(\mathrm{R}^{2}=\right.$ $0.279^{*}$ ) (Figure 4). The highest Fe concentration was found in the grains of ancestors of common wheat bearing the BB genome Aegilops speltoides, whose TGW was the lowest (Table 2). Similar values were reported for the non-essential elements strontium and aluminum (Kastori et al., 2017; Maksimović et al., 2020). Mineral substances in wheat grains are concentrated in the peripheral part, in the hull and aleurone layer of the grain (Peterson et al., 1983). The smaller the grain, the greater the weight of the peripheral portion in the total grain weight, which may contribute to higher concentrations of minerals in the grain as a whole. Svečnjak et al. (2013) determined a weak correlation between TGW and the concentration of microelements, except in cultivars differing significantly in TGW, which is in line with our results. Zhao et al. (2009) showed that there was a significant, but not strong, positive correlation between $\mathrm{Fe}$ concentration and kernel diameter, and a negative correlation between bran yields in 150 lines of bread wheat. 


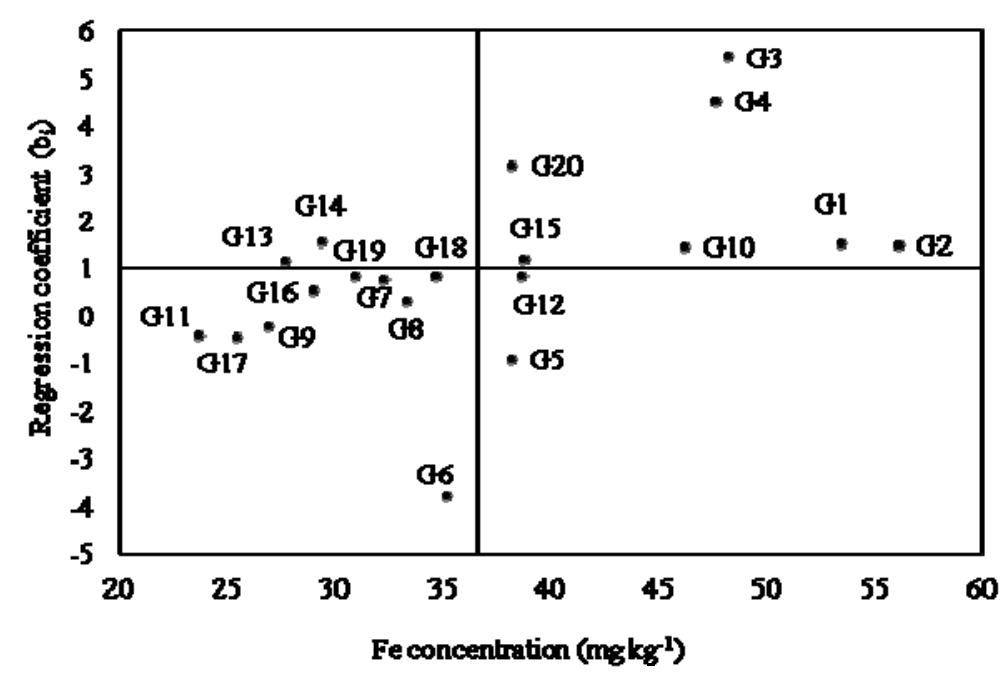

Figure 3. Iron concentration stability in analyzed genotypes

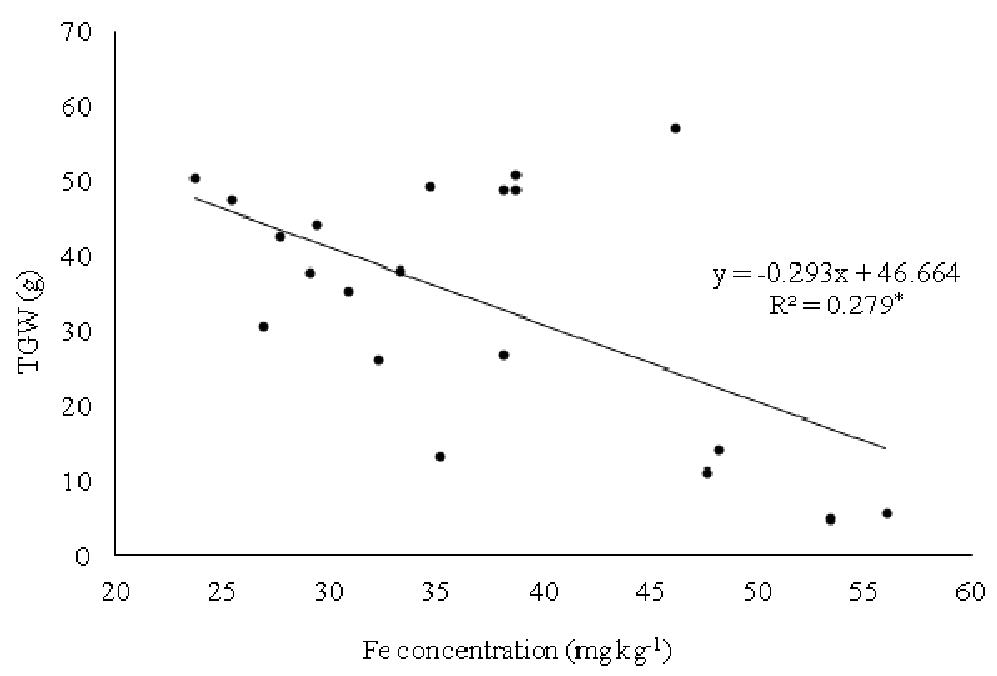

Figure 4. The relationship between grain Fe concentration and thousand grain weight (TGW) in Aegilops and Triticum genotypes

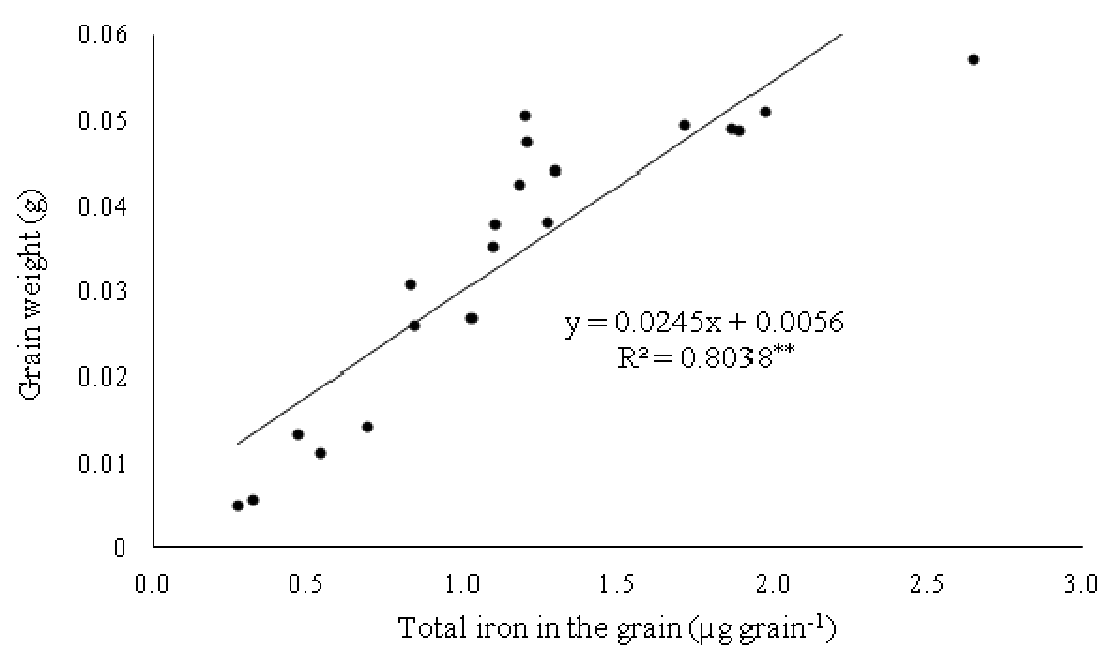

Figure 5. The relationship between total Fe in the grain and grain weight of Aegilops and Triticum genotypes 
The regression analysis showed that the amount of Fe in large individual grains in tetraploids BBAA and hexaploids BBAADD was higher than in the small grains in diploid genotypes bearing $\mathrm{BB}$ and $\mathrm{AA}$ genomes. The relationship between grain weight and Fe content in individual grains was significant $\left(\mathrm{R}^{2}=0.80\right.$; Figure 5). Similar results with respect to zinc in individual grains of diploid, tetraploid and hexaploid wheats were obtained by Cakmak et al. (1999). The values were 1.21 in diploid AA, 2.18 in tetraploid BBAA and $1.24 \mu \mathrm{g} \mathrm{Zn}$ grain $^{-1}$ in hexaploid BBAADD. During the development of contemporary cultivars, not only grain size but also Fe content in individual grains has increased. This suggests that during the increase in ploidy the capacity of tetraploid and hexaploid genotypes to uptake $\mathrm{Fe}$ from the soil increased concomitantly with an increase in the capacity of grains to serve as a sink for that Fe.

Although the concentration of $\mathrm{Fe}$ in plant-derived food and feed is very important, it is only one source of $\mathrm{Fe}$ for humans and animals. The bioavailability of $\mathrm{Fe}$ depends on a variety of substances present in different plant species and parts, such as phytate, polyphenols and cellulose in small grains, tannins in tea, oxalic acid in spinach leaves, and lecithin in most legumes and wheat (Graham, 2001). Moreover, contamination by heavy metals may reduce the bioavailability of $\mathrm{Fe}$. Phytate and polyphenols are considered "antinutrients" since they reduce the absorption of micronutrients in the intestines (Knez and Graham, 2013). The grains of small grains are rich in phytate (Branković et al., 2011), which is located predominantly in the aleuron layer and embryo. Phytate reduces the bioavailability of micronutrients, especially $\mathrm{Fe}$ and $\mathrm{Zn}$, in humans and monogastric animals (Fairweather-Tait, 2004). As reported by several studies, the reduction in $\mathrm{Fe}$ and $\mathrm{Zn}$ absorption in the presence of phytate ranged between 12 and 15 times. Hence, one possibility of increasing the provision of $\mathrm{Fe}$ is to create small grain genotypes with a lower content of phytate in the specific parts of the grain (Joyce et al., 2005). Phytate has many important roles in plant metabolism (Safrany et al., 1999) and, together with phenolics, in humans as well. Therefore, Bouis and Welch (2010) suggest that small grains breeding programs should focus more on increasing the content of $\mathrm{Fe}$ in the grain in order to provide its higher bioavailability than on reducing the content of phytate. Zhao et al. (2009) have found concomitant increases in the concentrations of $\mathrm{Fe}, \mathrm{Zn}$ and $\mathrm{P}$ in wheat lines during breeding. About $80 \%$ of phosphorus in the wheat grain is in the form of phytate, implicating the complexity of increasing the bioavailability of Fe by small grain breeding.

\section{Conclusions}

The species Aegilops and Triticum and genotypes within them differ significantly with respect to $\mathrm{Fe}$ content in the grain. The concentration of Fe spanned the range between 25.4 and $56.0 \mathrm{mg} \mathrm{kg}^{-1}$ of dry matter. The highest concentration of Fe was found in the wild, primitive diploids Aegilops speltoides (BB genome) and Triticum urartum (AA genome), whereas tetraploids and hexaploids had lower and similar values. Generally, the presence of $\mathrm{Fe}$ in the grain was higher in wild species than in contemporary cultivated genotypes, because, during breeding, the concentration of $\mathrm{Fe}$ decreased while grain weight increased, in other words the concentration of $\mathrm{Fe}$ was diluted due to breeding.
Thousand grain weight was the lowest in wild diploid species. There was a negative correlation between thousand grain weight and $\mathrm{Fe}$ concentration and a positive correlation between the concentration of $\mathrm{Fe}$ in a single grain and grain weight. However, the concentration of phytate is important for the bioavailability of $\mathrm{Fe}$ for humans and animals. The obtained results clearly showed great variability in $\mathrm{Fe}$ concentration between wheat genotypes, which can be used to increase $\mathrm{Fe}$ concentration in wheat cultivars and hence improve the quality of wheat with respect to Fe content.

\section{Acknowledgment}

The present research was financially supported by the Ministry of Education, Science and Technological Development of the Republic of Serbia, agreement No. 451-03-9/2021-14/200117. The authors are grateful to Prof. Srbislav Denčić for the plant material.

\section{Declaration of competing interest}

The authors declare that there is no conflict of interest.

\section{References}

Barker, A.V., Stratton, M.L. (2015). Iron. In: Barker, A.V., Pilbean, D.J. (Eds.), Handbook of Plant Nutrition. Second Edition. CRC Press Boca Raton London New York, 399426.

Batten, G.D. (1986). The uptake and utilization of phosphorus and nitrogen by diploid, tetraploid and hexaploid wheats (Triticum ssp.). Annals of Botany, 58, 49-59.

Bouis, H.E., Welch, R.M. (2010). Biofortification - a sustainable agricultural strategy for reducing micronutrient malnutrition in the global South. Crop Science, 50, 20-32.

Branković, G., Knežević, D., Dodig, D., Dragičević, V. (2011). Wheat breeding for low phytic acid content: state and perspectives. Field and Vegetable Crops Research. 48, 714.

Broadley, M., Brown, P., Cakmak, I., Rengel, Z., Zhao, F. (2012). Iron. In: Marschner, P. (Ed.), Marschner's Mineral Nutrition of Higher Plants. Third Edition, Elsevier Amsterdam, 191-200.

Cakmak, I., Tolay, I., Ozdemir, A., Ozkan, H., Ozturk, L., Klings, I. (1999). Differences in zinc efficiency among and within diploid, tetraploid and hexaploid wheats. Annals of Botany 84, 163-171.

Di Rienzo, J.A., Casanoves, F., Balzarini, M.G., Gonzalez, L., Tablada, M., Robledo, C.W. (2018). InfoStat versión 2018. InfoStat Group, Facultad de Ciencias Agropecuarias, Universidad Nacional de Córdoba, Argentina. URL http://www.infostat.com.ar.

Duxbury, M.A., Bodruzzaman, M., Lauren, J.M., Sadar, R.M., Welch, N., Elahi, E., Meisner, C.A. (2005). Increasing wheat and rice productivity in the sub-tropics using micronutrient enriched seed. In: Andersen, P. et al. (Eds.), Micronutrients in South and South East Asia. Proceedings of International Workshop, International Centre for Integrated Mountain Development, Kathmandu, Nepal, 187-198.

Eberhart, S.A. and Russell, W.A. (1966). Stability parameters for comparing varieties. Crop Science, 6, 36-40.

Edison, S., Bajel, A., Chandy, M. (2008). Iron homeostasis: new players, new insights. European Journal of Haematology, 81, 411-424.

Fairweather-Tait, S.J. (2004). Iron nutrition in the UK: getting the balance right. Proceedings of the Nutrition Society, 63: 519-528.

Frossard, E., Bucher, M., Maechler, F., Mazafar, A., Hurrel, R. (2000). Potential for increasing the content and 
bioavailability of $\mathrm{Fe}, \mathrm{Zn}$, and $\mathrm{Ca}$ in plants for human nutrition. Journal of the Science of Food and Agriculture, 80, 861-879

Graham, R.D., Senadhira, D., Beebe, S., Iglesias, C., Monasterrio, I. (1999). Breeding for micronutrient density in edible portions of staple food crops: conventional approaches. Field Crops Research, 60, 57-80.

Graham, R.D., Welch, R.M., Bouis, H.E. (2001). Addressing micronutrient malnutrition through enhancing the nutritional quality of staple foods: Principles, perspective and knowledge gaps. Advances in Agronomy, 70, 77-142.

Joyce, C., Deneau, A., Ockenden, I., Raboy, V., Lott, J.N.A. (2005). The concentrations and distributions of phytic acid phosphorus and other mineral nutrients in wild-type and low phytic acid Js-12-LPA wheat (Trticum aesativum) grain parts. Canadian Journal of Botany, 83, 1599-1607.

Kabata-Pendias, A. (2000). Trace Elements in Soils and Plants ( $3^{\text {rd }}$ edition). CRS Press, Boca Raton London New York Washington.

Kastori, R., Maksimović, I., Denčić, S., Kádár, I., Putnik-Delić. M. Momčilović, V. (2017). Strontium accumulation in whole grain of Aegilops and Triticum species. Journal of Plant Nutrition and Soil Science, 180, 212-219.

Knez, M., Graham, R.D. (2013). The impact of micronutrient deficiencies in agricultural soils and crops on the nutritional health of humans. In: Selinus, O. et al. (Eds.), Essentials of Medical Geology, Revised Edition. Springer Dordrecht Heidelberg New York London, 517-533.

Maksimović, I., Kastori, R., Putnik-Delić, M., Momčilović, V., Denčić, S., Mirosavljević, M. (2020). Genetic differences in $\mathrm{Al}$ accumulation in the grains of field grown Aegilops and Triticum. Plant, Soil and Environment, 66, 351-356.

Mengel, K. (1982). Response of various crop species and cultivars to mineral nutrition and fertilizer application. In: Genetic Specificity of Mineral Nutrition of Plant, Serbian Academy of Sciences and Arts, Belgrade, 22, 233245.

Morris, C.E., Sands, D.C. (2006). The breeder's dilemma - yield or nutrition? Nature Biotechnology, 24, 1078-1080.
Peterson, C.J., Johnson, V.A., Mattern, P.J. (1983). Evaluation of variation in mineral concentrations in wheat flour and bran of different cultivars. Cereal Chemistry, 60, 450-455.

Safrany, S.T., Caffery, J.J., Yang, X., Shears, S.B. (1999). Diphosphoinositol polyphosphates: the final frontier for inositide research. Biological Chemistry, 380, 945-951.

Sarić, M. (1981). Genetic specificity in relation to plant mineral nutrition. Journal of Plant Nutrition, 3, 743-766.

Svečnjak, Z., Jenel, M., Bujan, M., Vitali, D., Vedrina Dragojević, I. (2013). Trace element concentrations in the grain of wheat cultivars as affected by nitrogen fertilization. Agricultural and Food Science, 22, 445-451.

van Slageren, M.W. (1994). Wild Wheats: a monograph of Agilops L. and Amblyopyrum (Jaub. et Eig (Poaceae). ICARDA/Wageningen Agricultural University Papers, 94, $1-512$.

Welch, R.M., Allaway, W.H., House, W.A., Kubot, J. (1991). Geographic distribution of trace element problems. In: Mortvedt, J.J., Cox, F.R., Shuman, L.M., Welch, R.M. (Eds.), Micronutrients in Agriculture. Soil Sci. Soc. Am. Madison, 31-57.

Welch, R.M., Graham, R.D. (2004). Breeding for micronutrients in staple food crops from a human nutrition perspective. Journal for Experimental Botany, 55, 201-207.

Welch, R.M. (1999). Importance of seed mineral nutrient reserves in crop growth and development. In: Rengel, Z. (Ed.), Mineral Nutrition of Crops: fundamental mechanisms and implications. Food Products Press, New York.

WHO. (2011). World Health Statistics. World Health Organization, Geneva.

WHO. (2020). https://www.who.int/news-room/factsheets/detail/malnutrition (accessed February 25, 2021)

Zhao, F.J., Su, Y.H., Dunham, S.J., Rakszegi, M., Bedo, Z., McGrath, S.P., Shewry, P.R. (2009). Variation in mineral micronutrient concentrations in grain of wheat lines of diverse origin. Journal of Cereal Science, 49, 290-295. 